GRASAS Y ACEITES, 63 (2), ABRIL-JUNIO, 193-201, 2012, ISSN: 0017-3495

DOI: $10.3989 /$ gya.095011

\title{
Physico-chemical characteristics of seed oils extracted from different apricot (Prunus armeniaca L.) varieties from Pakistan
}

\author{
By M. Manzoor ${ }^{1}$, F. Anwar ${ }^{1,2, *}$, M. Ashraf ${ }^{3,4}$ and K.M. Alkharfy ${ }^{5}$ \\ ${ }^{1}$ Department of Chemistry and Biochemistry, University of Agriculture Faisalabad-38040, Pakistan \\ ${ }^{2}$ Department of Chemistry, University of Sargodha-40100, Sargodha, Pakistan \\ ${ }^{3}$ Department of Botany, University of Agriculture Faisalabad-38040, Pakistan \\ ${ }^{4}$ Department of Botany and Microbiology, King Saud University, Riyadh, Saudi Arabia \\ ${ }^{5}$ Department of Clinical Pharmacy, College of Pharmacy, King Saud University, Riyadh, Saudi Arabia \\ ${ }^{*}$ Corresponding author: fqanwar@yahoo.com
}

\section{RESUMEN}

Características físico-químicas de aceites de semillas extraídos de diferentes variedades de albaricoque (Prunus armeniaca L.) de Pakistán.

Se han analizado las características físico-químicas de aceites de semillas de frutos de cuatro variedades diferentes de albaricoque, Halmas, Nari, Travet y Charmagzi (Prunus armeniaca L.). La producción de aceites de las semillas de albaricoque (hueso) osciló entre 32,23-42,51\%, mientras que las proteínas, fibra y cenizas dieron valores de $13,21-20,90 \%$, $5,13-9,81 \%$ y $2,11-3,89 \%$, respectivamente. Los aceites extraídos presentaron valores promedio de índice de yodo, de $96,4-106,3$ ( $\mathrm{g}$ de $\mathrm{l} / 100 \mathrm{~g}$ de aceite); densidades a $24^{\circ} \mathrm{C}$ de 0,87-0,93 $\mathrm{mg} / \mathrm{mL}$, índices de refracción $\left(40^{\circ} \mathrm{C}\right)$ de 1,46551,4790; índices de saponificación de 189.1-199,4 (mg KOH/g de aceite), materia insaponificable de 0,59-0,88\%, valores de acidez libre de $0.41-1.28$ ( $\mathrm{mg}$ de $\mathrm{KOH} / \mathrm{g}$ de aceite), y valores de color de 1,31-2.96R 14,8-29,8Y (celda de 1 pulgada). Con respecto al estado de oxidación de los aceites estudiados, estos mostraron valores de extinción específica a 232 y 268 nm de 2,30-3,42 y 0,82-1,04, respectivamente, mientras que dieron valores de índices de peróxidos de 1,0-2,32 meq $\mathrm{O}_{2} / \mathrm{kg}$ y de p-anisidina de 1,22-1,90. El principal ácido graso que se encuentra en los aceites fue el ácido oleico (62,34 -80,97\%), seguido de linoleico $(13,13-30,33 \%)$, palmítico $(3,35-5,93 \%)$, linolénico $(0,73-1,03 \%)$ y esteárico $(1,10$ a $1,68 \%)$. El contenido de $\alpha$-, $\gamma$ - y $\delta$ - tocoferoles en los aceites variaron desde 14,8 hasta $40,4,330,8$ a 520,8 y 28,5 hasta 60,2 mg/kg, respectivamente. Los resultados de nuestra investigación actual revela que la semilla de albaricoque es una fuente potencial de aceite que puede ser utilizado tanto para aplicaciones comestibles como oleoquímicas.

PALABRAS CLAVE: Ácidos grasos - Albaricoque (Prunus armeniaca L.) - Parámetros de oxidación - Tocoferoles.

\section{SUMMARY}

Physico-chemical characteristics of seed oils extracted from different apricot (Prunus armeniaca L.) varieties from Pakistan.

The fruit seed oils from four varieties of apricot (Prunus armeniaca L.), namely, Halmas, Nari, Travet and Charmagzi were analyzed for different physico-chemical characteristics. The oil yield from the apricot seeds (kernels) ranged from $32.23-42.51 \%$, while the protein, fiber and ash contents ranged from $13.21-20.90 \%, 5.13-9.81 \%$ and $2.11-3.89 \%$, respectively. The extracted oils had an average iodine value ( $\mathrm{g}$ of $\mathrm{I} / 100 \mathrm{~g}$ of oil) of $96.4-106.3$; density at $24^{\circ} \mathrm{C}$, $0.87-0.93 \mathrm{mg} / \mathrm{mL}$; refractive index $\left(40^{\circ} \mathrm{C}\right), 1.4655-1.4790$; saponification value, $189.1-199.4 \mathrm{mg}$ of $\mathrm{KOH} / \mathrm{g}$ oil; unsaponifiable matter, $0.59-0.88 \%$; free fatty acid $(\mathrm{mg}$ of $\mathrm{KOH} / \mathrm{g}$ oil), 0.41-1.28; and color (1-inch cell), 1.31-2.96R + $14.8-29.8 Y$. With regard to the oxidation state, the tested oils showed values for specific extinction at 232 and $268 \mathrm{~nm}$, 2.30-3.42 and 0.82-1.04, respectively, while the peroxide value was 1.0-2.32 $\mathrm{meq} \mathrm{O}_{2} / \mathrm{kg}$ and, $p$-anisidine was 1.22-1.90. The major fatty acid found in the oils was oleic acid (62.34-80.97\%) followed by linoleic (13.13-30.33\%), palmitic (3.35-5.93\%), linolenic (0.73-1.03\%) and stearic (1.10-1.68\%) acids. The contents of $\alpha-, \gamma-$, and $\delta$-, tocopherols in the oils ranged from $14.8-40.4,330.8-520.8$ and $28.5-60.2 \mathrm{mg} / \mathrm{kg}$, respectively. The results of our present investigation revealed that apricot seed is a potential source of oil which can be used both for edible and oleochemical applications.

KEY-WORDS: Apricot (Prunus armeniaca L.) - Fatty acids - Oxidation parameters - Tocopherols.

\section{INTRODUCTION}

Prunus, belonging to family Rosaceae, is a large genus consisting of about 430 species of both evergreen and deciduous trees and shrubs, distributed across the Northern Hemisphere and into the sub-tropics and tropic regions around the globe (Lee and Wen, 2001, Wen et al., 2008). Apricot (Prunus armeniaca L.) is also an important fruit tree of the family Rosaceae. However, it is mostly grown in Mediterranean countries as well as in Pakistan, USA, Iran and Russia (Hussain et al., 2011). The plant is well known for its great medicinal and economical importance. For example, its different parts are used in traditional medicine for the treatment of a variety of common diseases such as cough, asthma, bronchitis, anemia and fever (Fazlin et al., 2002, Panda, 2004; Erdogen-Orhan and Kartal, 2011).

Apricot kernels, after removing the stone, are used as appetizers or used as food additives (Demir and Cronin, 2005; Asma et al., 2007). The seed 
kernels also possess antioxidant, anti-asthamic, antitussive, and anti-pasmodic activity (Durmaz and Alpaslan, 2007; Erdogen-Orhan and Kartal, 2011). The kernel is a rich source of dietary protein as well as oil and fiber. Presently, although the cosmetic industry is the principal utilizer of apricot kernel oil, it can also be used for edible purposes due to its considerably high nutritive value (Durmaz and Alpaslan, 2007; Turan et al., 2007; Abdel-Rahman, 2011).

The apricot is one of the major fruits of the northern areas of Pakistan. It is most commonly grown in Hunza, Baluchistan, Gilgit and Kyber Pukhtonkha (Fazlin et al., 2002). Due to the distinct aroma of the apricot fruit, it is used for preparing jams and nectars. In Pakistan, apricots are primarily preserved in dried form using some known traditional processes (Hussain et al., 2010). The dried apricot fruit is available in the market throughout the year, while fresh fruit is available in the market from May to September (Faqir et al., 2004; Gezer et al., 2011). In order to maintain the consistent supply of oils and fats these days for an ever-increasing demand, it has become indispensable to explore new and non-conventional potential sources of oil. As a result, a considerable amount of oils and fats is being derived from plant sources. In the last few decades, there has been a growing interest in exploring new sources of edible oils with high nutritional, industrial and pharmaceutical values (Cerchiara et al., 2010; Nehdi et al., 2010; Nehdi, 2011).

A large number of fruit seeds is usually discarded by the food processing industry, which could be a precious source of raw material (El-Adawy and Taha, 2001). Apparently, such an application would help maximize available resources and result in generating a variety of various new foods. For example, watermelon, citrus, parika, papaya, muskmelon, pumpkin and apricot seeds, which remain in large quantity as waste products after the removal of pulp and peel, could be utilized both for the production of oil and other important byproducts (Liangli et al., 2005; Matthaus and Ozcan, 2009).

Many studies have been conducted to assess the physical, chemical and nutritional properties of the seeds of different fruits (Topuz et al., 2004; Naderiboldaji et al., 2008; Radicevic et al., 2008; Ozcan et al., 2010). For example, the fruit seeds of raspberry (Oomah et al., 2000), apple and pear (Yukui et al. 2009), sweet cherry (Kalyoncu et al., 2009), apricot (Turan et al., 2007) and wine grapes (Baydar, 2001) have been characterized for oil composition and mineral contents. A great magnitude of varietal variation in fruit or fruit seed composition has been reported in all these studies.

The consumption and processing of apricot fruits generates a huge quantity of apricot seeds, which could be potentially utilized for the production of oil. A survey of the literature has revealed that no detailed studies on the composition and characteristics of apricot seeds and seed oil from
Pakistan have yet been reported. Thus, the main objective of the present study was to evaluate the detailed physico-chemical characteristics, fatty acid composition and tocopherol contents of fruit seed oils extracted from four different varieties of apricot (Prunus armeniaca L.) commonly grown in Pakistan.

\section{MATERIALS AND METHODS}

\subsection{Collection of samples}

Fully ripened fruits of four sweet varieties of apricot (Prunus armeniaca L.), namely Halmas, Nari, Travet and Charmagzi were collected from the vicinity of Swat, Khyber and Pukhtonkha, Pakistan. Three different fruit samples for each variety were harvested. The sweet kernels were removed manually from the fruits, washed with tap water and then dried at $40^{\circ} \mathrm{C}$ in an oven (EYELA, VOC-300 SD, Tokyo, Japan) for $24 \mathrm{~h}$. All reagents (analytical and HPLC) used were from Merck (Darmstadt, Germany) or Sigma Aldrich (Buchs, Switzerland). Pure standards of tocopherols [DL- $\alpha$-tocopherol, $(+)$ - $\gamma$-tocopherol, $(+)$ - $\delta$-tocopherol], and FA methyl esters (FAMEs) were obtained from Sigma Chemical Co. (St Louis, MO, USA).

\subsection{Oil extraction}

After the removal of the seed coating, the seed kernels $(50 \mathrm{~g})$ of the different varieties of apricot were crushed using a commercial blender (TSK949, West Point, France). The crushed material, packed in a paper thimble, was placed in a Soxhlet extractor connected with a condenser and a $500 \mathrm{~mL}$ round bottom flask. The extraction was performed with $n$-hexane $(250 \mathrm{~mL})$ in a water bath for $6 \mathrm{~h}$. After completion of the extraction process, the excess solvent was removed under reduced pressure using a rotary evaporator (EYELA, N-N Series; Rikakikai Co Ltd., Tokyo, Japan).

\subsection{Analysis of oilseed residues}

The oil seed residues (meal) remaining after the extraction of the oil from the seeds were analyzed for protein, fiber and ash contents. Protein content was determined according to the Association of Official Analytical Chemists (AOAC) standard method 976.06 (AOAC, 1990). Fiber content was determined according to the International Standards Organization (ISO) method 5983 (ISO, 1981). The ground meal material $(2.5 \mathrm{~g})$ was weighed and freed from fat by extraction with $15 \mathrm{~mL}$ of $n$-hexane. The test portion was boiled with a sulfuric acid solution $(0.255 \mathrm{~mol} / \mathrm{L})$, the insoluble residues were separated and washed. The residue was then boiled with sodium hydroxide $(0.313 \mathrm{~mol} / \mathrm{L})$, followed by separation, washing and drying. The pre-weighed dried residue material was ashed in a muffle furnace (EYELA, TMF-2100, Tokyo, Japan) at $600^{\circ} \mathrm{C}$ and the loss of mass was calculated. For 
ash determination, two grams of the test portion were taken and carbonized by heating on a gas flame. The carbonized material was then ashed in an electric muffle furnace (EYELA, TMF-2100, Tokyo, Japan) at $550^{\circ} \mathrm{C}$ until a constant mass was achieved (ISO, 1977).

\subsection{Analysis of extracted oil}

Determinations of physical and chemical parameters including density, refractive index, iodine value, peroxide value, acidity, saponification value and unsaponifiable matter of the oils were made following standard AOCS methods Cc 10a-25, Cc 7-25, Cd 1-25, Cd 8-53, F 9a-44, Cd 3-25 and Ca 61-40, respectively (AOCS, 1997). The color of the oils was determined by a Lovibond tintometer (Tintometer Ltd., Salisbury, Wiltshire, United Kingdom), using a 1-inch cell. Conjugated dienes and trienes in terms of specific extinctions at 232 and $268 \mathrm{~nm}$, respectively, were monitored using a UV-visible spectrophotometer (U-2001, Hitachi Instruments Inc. Tokyo, Japan). The absorbance of the oil samples, properly diluted with iso-octane, was recorded and $\varepsilon^{1 \%}{ }_{1 \mathrm{~cm}} \lambda_{232 \text { and }} \varepsilon^{1 \%}{ }_{1 \mathrm{~cm}} \lambda_{268}$, values which were calculated following the IUPAC method II.D.23 (Anon., 1987). The p-anisidine value was determined according to the IUPAC method II.D.26 (Anon., 1987). The oil samples were dissolved in iso-octane and allowed to react with $p$-anisidine reagent in acetic acid $(0.25 \% \mathrm{w} / \mathrm{v})$ for $10 \mathrm{~min}$ to produce a colored complex, the absorbance of which was recorded at $350 \mathrm{~nm}$ using a spectrophotometer (U-2001, Hitachi Instruments Inc. Tokyo, Japan).

\subsection{Tocopherol analysis}

An HPLC method, based on the current protocols in the Food Analytical Chemistry method (Wrolstad, 2003) was used to analyze tocopherols $(\alpha, \gamma$, and $\delta)$. In a test tube $(16 \times 25)$ containing oil $(0.1 \mathrm{~g})$ and ascorbic acid $(0.05 \mathrm{~g}), 5 \mathrm{~mL}$ of $90 \%$ ethanol and $0.5 \mathrm{~mL}$ of $80 \%$ aqueous $\mathrm{KOH}$ solution were added. The test tube was vortexed for $30 \mathrm{~s}$, flushed with nitrogen, capped and incubated in a water bath $\left(70^{\circ} \mathrm{C}\right)$ for $30 \mathrm{~min}$ with periodical vortexing. The tube was placed in an ice bath for 5 min, then $3 \mathrm{~mL}$ deionized water and $5 \mathrm{~mL} n$-hexane were added to each tube. Thereafter, the tube was vortexed for $30 \mathrm{~s}$ followed by centrifugation at $1,000 \times g$ for $10 \mathrm{~min}$ at room temperature. The upper hexane layer was decanted to another test tube. The aqueous layer and the residue recovered were re-extracted by repeating the same procedure. The upper hexane layers from both extractions were pooled and evaporated to dryness by nitrogen streaming. The extract material obtained was redissolved in one $\mathrm{mL}$ of mobile phase by vortexing for $30 \mathrm{~s}$ and then transferred to an HPLC sample vial. A $20-\mu \mathrm{L}$ sample was injected into a Supelcosil LC-Si column $(250 \times 4.6 \mathrm{~mm}$, Supelco Inc. $)$. A mobile phase consisting of ethyl acetate/acetic acid/hexane $(1: 1: 198, \mathrm{v} / \mathrm{v} / \mathrm{v})$ was used at a flow rate of $1.5 \mathrm{~mL} / \mathrm{min}$. The detection of tocopherol isomers was done at $295 \mathrm{~nm}$. Tocopherols were identified by comparing the retention times with those of pure standards of $\alpha-, \gamma$ - and $\delta$-tocopherols. These were quantified on the basis of peak areas of the pure standards (Sigma Chemical Co.), while the quantification was based on an external standard method. A D-2500 Hitachi Chromatointegrator model with a built-in computer program for data handling was used for quantification purposes.

\subsection{Gas chromatographic fatty acid (FA) analysis}

The apricot seed oils were analyzed as fatty acid methyl esters (FAMEs), prepared using the standard IUPAC method 2.301 (IUPAC, 1987). The separation of the FAMEs was carried out on a Perkin-Elmer model 8700 gas chromatograph (Norwalk, CT, USA), fitted with a flame ionization detection (FID) system and a RT-2560 capillary column (100 m ×0.25 mm, film thickness $0.20 \mu \mathrm{m})$. A sample of $1.0 \mu \mathrm{L}$ was injected into the column using the split mode (split ratio, 1:100) and flushed through the column with helium as carrier gas at a flow rate of $1.2 \mathrm{~mL} / \mathrm{min}$. The column oven temperature was started at 150 and raised to $250^{\circ} \mathrm{C}$ at $4^{\circ} \mathrm{C} / \mathrm{min}$ with initial and final hold-up times of 1 and $5 \mathrm{~min}$, respectively. The injector and detector were set at 250 and $260^{\circ} \mathrm{C}$, respectively. FAMEs were identified by matching their relative and absolute retention times to those of authentic standards from Sigma-Aldrich Chemical Co. (St. Louis, MO). The authentic standards were used for performing the quantitative analysis using a calibration curve. All quantitative measurements were made by gas chromatograph built-in data handling software (Perkin-Elmer, Norwalk, CT, USA). The fatty acid composition was reported as the relative percentage of the total peak area.

\subsection{Gas chromatographic/mass spectrometric (GC/MS) fatty acid (FA) analysis}

The FAMEs were further analyzed by Agilent technologies (Little Falls, CA, USA) 6890N Network GC system, equipped with an Agilent-Technologies 5975 inert XL Mass selective detector and AgilentTechnologies' 7683B series auto-injector. An Agilent-Technologies RT-2560 capillary column (100 m × $0.25 \mathrm{~mm}$, film thickness $0.20 \mu \mathrm{m})$, operated under the same chromatographic conditions as used previously for GC analysis, was used for separation purposes. For GC/MS detection, an electron ionization system (ionization energy of $70 \mathrm{eV}$ ) was used. The injector and MS transfer line temperatures were set at 250 and $260^{\circ} \mathrm{C}$, respectively. The scanning mass range varied over $30-550 \mathrm{~m} / \mathrm{z}$. The identification of the unknown FAMEs was based on the comparison of their 
relative retention times with those of authentic standards of FAMEs (Sigma Chemical Co., St Louis, MO, USA). The identification of FAMEs was also authenticated using their MS spectra compared to those from the NIST mass spectral library of the GC/MS system.

\section{RESULTS AND DISCUSSION}

Table 1 depicts the data for the proximate analysis of seeds (kernels) of four different varieties of apricot. The oil content in the tested apricot seed kernels ranged from $32.23-42.51 \%$, thus advocating that apricot kernel could be considered as a rich source of oil. The oil contents of var. Charmagzi were found to be highest $(42.51 \%)$ whereas the lowest $(32.23 \%)$ was found for Halmas. According to analysis of variance (ANOVA) a significant variation $(p<0.05)$ was observed in the oil contents of different apricot varieties, which might be mainly attributed to inter-varietal differences.

The results of our present study are in good agreement with those reported (28.26-42.43\%) for different varieties of apricot kernel from Turkey (Gezer et al., 2011). Femenia et al., (1995) reported that the kernel of sweet apricot varieties collected from Mallorca (Spain) contained 49.8-56.1\% oil, which was quite higher than the percentages reported in our present study. The apricot seed oil content reported in our investigation is lower than that reported for different Prunus species (46.3-55.4\%) from Turkey (Matthaus and Ozcan, 2009). In another study, the kernel oil content of apricot was found to be within the range of 42.2$57.2 \%$ (Ozcan et al., 2010), which is higher than that found in the present investigation. The high oil content in apricot fruit seeds is also comparable to commonly used oils of oilseed crops such as soybean, canola and sunflower. So the oil from apricot seeds could be exploited as a commodity of high commercial value.

The analysis of the oilseed residues after oil extraction revealed the protein contents to be $13.21-20.90 \%$ and the varieties differed considerably in these contents. The kernel of var. Charmagzi exhibited the highest protein contents $(20.90 \%)$, whereas var. Halmas had the lowest (13.21\%) of all cultivars. The protein contents recorded in the present analysis were found to be lower than those reported (23.58-27.70\%) in the different varieties of apricot from Turkey (Ozcan, 2000). However, our results were comparable to those investigated (15.7-18.3) for apricot kernel by Gezer et al., (2011) from Turkey. The present determination of apricot seed revealed the meal to be a good source of protein and thus it could be utilized as potential animal food stuff as well as for fertilizer applications. The ash and fiber contents of the tested varieties of apricot kernel ranged from $2.11-3.89 \%$ and $5.13-$ $9.81 \%$, respectively. The crude fiber and ash contents as determined in the present analysis were comparable to those reported (4.06-7.63\% and $2.13-3.45 \%$ ) for apricot kernel from Turkey (Ozcan et al., 2010).

The results for the physico-chemical characteristics of the extracted oils from the different varieties of apricot kernels are presented in Table 2. The investigated apricot oils exhibited a significant $(p<0.05)$ variation for most of the physico-chemical characteristics such as iodine value, density, saponification and unsaponifiable matter.

The values of refractive index $\left(40^{\circ} \mathrm{C}\right)$ and density $\left(24^{\circ} \mathrm{C}\right)$ of the tested oils were $1.4655-1.4790$ and $0.87-0.93$, respectively. The iodine value (IV) ( $g$ of $\mathrm{I} / 100 \mathrm{~g}$ of oil) demonstrates the levels of unsaturation and potential oxidative sensitivities of the oils. As oil and fat deteriorate due to oxidation, so their iodine value reduces (Moodley et al., 2007). The four tested apricot kernel oils ranged from 96.4 (var. Nari) to 106.3 (var. Charmagzi). The results of our present investigation in comparison with other nonconventional seed oils were within the range of those reported (95.8-124.0) in melon seed oil (Mabaleha et al., 2006). However, the present value was found to be higher than those reported for mango kernel (39-48) and almond kernel (88.8-96.1) oils (Moayedi et al., 2010).

The saponification number and unsaponifiable matter of the tested apricot kernel oils ranged from 189.1-199.4 mg of $\mathrm{KOH} / \mathrm{g}$ of oil and 0.59$0.88 \%$, respectively. The saponification and unsaponifiable matter of var. Charmagzi was

Table 1

Proximate analysis of fruit seeds of four varieties of apricot (Prunus armeniaca L.)

\begin{tabular}{lrrrr}
\hline \multirow{2}{*}{$\begin{array}{c}\text { Constituents } \\
\text { (\%) }\end{array}$} & \multicolumn{4}{c}{ Nariety } \\
\cline { 2 - 5 } & \multicolumn{1}{c}{ Nari } & \multicolumn{1}{c}{ Halmas } & \multicolumn{1}{c}{ Travet } & \multicolumn{1}{c}{ Charmagzi } \\
\hline Oil & $39.80 \pm 1.10^{\mathrm{b}}$ & $32.23 \pm 0.69^{\mathrm{c}}$ & $35.99 \pm 0.68^{\mathrm{c}}$ & $42.51 \pm 0.79^{\mathrm{a}}$ \\
Moisture & $5.04 \pm 0.13^{\mathrm{b}}$ & $5.54 \pm 0.13^{\mathrm{b}}$ & $6.43 \pm 0.14^{\mathrm{a}}$ & $4.11 \pm 0.09^{\mathrm{c}}$ \\
Protein & $16.12 \pm 0.29^{\mathrm{ab}}$ & $13.21 \pm 0.27^{\mathrm{b}}$ & $18.12 \pm 0.17^{\mathrm{a}}$ & $20.90 \pm 0.21^{\mathrm{a}}$ \\
Ash & $2.11 \pm 0.04^{\mathrm{b}}$ & $2.92 \pm 0.05^{\mathrm{ab}}$ & $3.89 \pm 0.07^{\mathrm{a}}$ & $3.40 \pm 0.07^{\mathrm{a}}$ \\
Fiber & $5.13 \pm 0.09^{\mathrm{c}}$ & $5.92 \pm 0.13^{\mathrm{c}}$ & $9.81 \pm 0.17^{\mathrm{a}}$ & $6.76 \pm 0.11^{\mathrm{b}}$ \\
\hline
\end{tabular}

Values are means \pm SD of triplicate determinations. Different letters in superscript within the same row indicate significant differences among the varieties tested. 
Table 2

Physicochemical characteristics of seed oils of different varieties of apricot (Prunus armeniaca L.)

\begin{tabular}{lrrrr}
\hline \multirow{2}{*}{ Constituents } & \multicolumn{3}{c}{ Variety } \\
\cline { 2 - 5 } & \multicolumn{1}{c}{ Nari } & \multicolumn{1}{c}{ Halmas } & \multicolumn{1}{c}{ Travet } & \multicolumn{1}{c}{ Charmagzi } \\
\hline Refractive Index $\left(40^{\circ} \mathrm{C}\right)$ & $1.4771 \pm 0.03^{\mathrm{a}}$ & $1.4655 \pm 0.02^{\mathrm{b}}$ & $1.4669 \pm 0.03^{\mathrm{b}}$ & $1.4790 \pm 0.02^{\mathrm{a}}$ \\
Density $\left(24^{\circ} \mathrm{C}\right)$ & $0.90 \pm 0.02^{\mathrm{a}}$ & $0.87 \pm 0.04^{\mathrm{b}}$ & $0.91 \pm 0.02^{\mathrm{a}}$ & $0.93 \pm 0.03^{\mathrm{a}}$ \\
Saponification value $(\mathrm{mg}$ of $\mathrm{KOH} / \mathrm{g}$ of oil) & $196.3 \pm 4.1^{\mathrm{ab}}$ & $199.4 \pm 2.9^{\mathrm{a}}$ & $192.4 \pm 3.7^{\mathrm{ab}}$ & $189.1 \pm 3.23^{\mathrm{b}}$ \\
Unsaponifiable matter $(\%)$ & $0.65 \pm 0.02^{\mathrm{c}}$ & $0.88 \pm 0.04^{\mathrm{a}}$ & $0.72 \pm 0.02^{\mathrm{b}}$ & $0.59 \pm 0.01^{\mathrm{d}}$ \\
lodine Value $(\mathrm{g}$ of $\mathrm{l} / 100 \mathrm{~g}$ of oil) & $96.4 \pm 1.9^{\mathrm{b}}$ & $102.5 \pm 2.8^{\mathrm{ab}}$ & $99.9 \pm 2.3^{\mathrm{b}}$ & $106.3 \pm 2.12^{\mathrm{a}}$ \\
Color (red unit) & $1.31 \pm 0.03^{\mathrm{b}}$ & $2.96 \pm 0.05^{\mathrm{a}}$ & $1.79 \pm 0.02^{\mathrm{b}}$ & $2.73 \pm 0.04^{\mathrm{a}}$ \\
Color (yellow unit) & $14.8 \pm 0.30^{\mathrm{c}}$ & $29.8 \pm 0.61^{\mathrm{a}}$ & $19.9 \pm 0.42^{\mathrm{b}}$ & $22.6 \pm 0.46^{\mathrm{b}}$ \\
Free Fatty Acids (\% as oleic acid) & $0.93 \pm 0.06^{\mathrm{b}}$ & $1.28 \pm 0.04^{\mathrm{a}}$ & $0.81 \pm 0.05^{\mathrm{b}}$ & $0.41 \pm 0.01^{\mathrm{c}}$ \\
\hline
\end{tabular}

Values are means $\pm S D$ of triplicate determinations. Different letters in superscript within the same row indicate significant differences among the varieties tested.

found to be lowest (189.1 and 0.59) and that of var. Halmas the highest (199.4 and 0.88) of all the apricot varieties. The saponification values determined in the present analysis of kernel oils were quite comparable with those of almond kernel (188-196), mango kernel (188-195), raspberry seed (187-192) and grape seed (188194) oils (Rossell, 1991). However, these values were found to be higher than those reported (180182) in bitter and sweet apricot kernel oil (Hussain et al., 2011). The unsaponifiable matter of apricot kernel oil was within the range of palm kernel $(0.2-0.8 \%)$, grape seed $(0-2.0 \%)$, apricot kernel $(0.30-1.58 \%)$, mango kernel $(0.5-2.9 \%)$ and pumpkin seed (0.6-1.5\%) oils (Rossell, 1991). The free fatty acid (FFA) contents of the investigated apricot kernel oils ranged from $0.41-1.28 \%$. The highest $(1.28 \%)$ and the lowest $(0.41 \%)$ FFA contents were determined in the apricot kernels oil of var. Halmas and var. Charmagzi, respectively. FFAs are mainly the product of hydrolysis and their presence in oils is linked to the development of objectionable flavor and odors. The FFA contents of freshly extracted vegetable oils are generally below $1 \%$ (Oderinde et al., 2009). The present FFA contents when compared with some other seed oils were lower than those reported for melon seed (1.2-4.0\%) (Mabaleha, 2006), citrus seed $(0.50-2.18 \%)$
(Anwar et al., 2008) and almond kernel (1.38$3.55 \%$ ) oils (Ozcan et al., 2011).

The results for the oxidative stability of apricot kernel oils are presented in Table 3 . The specific extinctions at 232 and $268 \mathrm{~nm}$ in terms of dienes and trienes, respectively, of apricot kernel oils ranged from 2.30-3.42 and 0.82-1.04, respectively. The dienes and trienes reported presently were higher than those reported in grape $(0.467$ and $0.089)$, safflower (0.514 and 0.134$)$ and raspberry (0.837 and ND) seed oils (Oomah et al., 2000). The peroxide and $p$-anisidine values were found to be $1.00-2.32 \mathrm{meqO}_{2} / \mathrm{kg}$ of oil and 1.22-1.90, respectively. Among the varieties tested, apricot kernel oil (var. Charmagzi) exhibited the highest peroxide (2.32meq/kg of oil) and p-anisidine (1.90) values, whereas, var. Travet exhibited the lowest (1.00 $\mathrm{meqO}_{2} / \mathrm{kg}$ and 1.22$)$, indicating high resistance to primary and secondary oxidation. The peroxide values determined in the present analysis were below the maximum established in the regulation for vegetable oils $\left(10 \mathrm{meqO}_{2} / \mathrm{kg}\right)$, indicating a good oxidative stability of apricot seed oils (Pardo et al., 2009). The peroxide and $p$-anisidine values determined in our present analysis were lower than those reported for melon seed oil (1.1-10.9 $\mathrm{meqO}_{2} / \mathrm{kg}$ and 0.2-9.0) (Mabaleha et al., 2006) and raspberry seed oil $\left(8.25 \mathrm{meqO}_{2} / \mathrm{kg}\right.$ and 14.3) (Oomah et al., 2000).

Table 3

Oxidative stability of seed oils of different varieties of apricot (Prunus armeniaca L.)

\begin{tabular}{lcccc}
\hline \multicolumn{1}{c}{ Constituents } & \multicolumn{3}{c}{ Variety } \\
\cline { 2 - 5 } & Nari & Halmas & Travet & Charmagzi \\
\hline Peroxide value $\left(\mathrm{meqO}_{2} / \mathrm{kg}\right)$ & $1.65 \pm 0.03^{\mathrm{b}}$ & $1.12 \pm 0.03^{\mathrm{c}}$ & $1.00 \pm 0.03^{\mathrm{c}}$ & $2.32 \pm 0.04^{\mathrm{a}}$ \\
$p$-anisidine value & $1.53 \pm 0.03^{\mathrm{b}}$ & $1.28 \pm 0.03^{\mathrm{c}}$ & $1.22 \pm 0.05^{\mathrm{c}}$ & $1.90 \pm 0.06^{\mathrm{a}}$ \\
Conjugated diene $\varepsilon^{1 \%}{ }_{1 \mathrm{~cm}} \lambda_{232}$ & $2.49 \pm 0.02^{\mathrm{c}}$ & $2.30 \pm 0.03^{\mathrm{c}}$ & $3.42 \pm 0.04^{\mathrm{a}}$ & $2.73 \pm 0.02^{\mathrm{b}}$ \\
Conjugated triene $\varepsilon^{1 \%}{ }_{1 \mathrm{~cm}} \lambda_{268}$ & $0.89 \pm 0.02^{\mathrm{c}}$ & $1.04 \pm 0.03^{\mathrm{a}}$ & $0.82 \pm 0.04^{\mathrm{c}}$ & $0.93 \pm 0.02^{\mathrm{c}}$ \\
\hline
\end{tabular}

Values are means $\pm S D$ of triplicate determinations. Different letters in superscript within the same row indicate significant differences among the varieties tested. 
Table 4

Tocopherol contents of seed oils $(\mathrm{mg} / \mathrm{kg})$ of different varieties of apricot (Prunus armeniaca L.)

\begin{tabular}{lcccc}
\hline \multirow{2}{*}{ Tocopherols } & \multicolumn{4}{c}{ Variety } \\
\cline { 2 - 5 } & Nari & Halmas & Travet & Charmagzi \\
\hline$\alpha$-tocopherol & $24.9 \pm 0.5^{\mathrm{b}}$ & $14.8 \pm 0.3^{\mathrm{c}}$ & $29.1 \pm 0.6^{\mathrm{b}}$ & $40.4 \pm 0.8^{\mathrm{a}}$ \\
$\gamma$ - tocopherol & $451.3 \pm 8.9^{\mathrm{b}}$ & $371.9 \pm 7.6^{\mathrm{c}}$ & $330.8 \pm 6.7^{\mathrm{c}}$ & $520.8 \pm 11.2^{\mathrm{a}}$ \\
$\delta$-tocopherol & $60.2 \pm 1.3^{\mathrm{a}}$ & $28.5 \pm 0.5^{\mathrm{c}}$ & $41.7 \pm 0.8^{\mathrm{b}}$ & $38.4 \pm 0.8^{\mathrm{b}}$ \\
\hline
\end{tabular}

Values are means \pm SD of triplicate determinations. Different letters in superscript within the same row indicate significant differences among the varieties tested.

The tocopherol contents as determined for apricot kernel oils exhibited a significant variation $(p<0.05)$ among the varieties analyzed (Table 4$)$. Three tocopherol isomers $(\alpha-, \gamma-$, and $\delta$ ) were identified and quantified in the oil. Gammatocopherol was found to be the most abundant falling within the range of $330.8-520.8 \mathrm{mg} / \mathrm{kg}$. The contents of $\gamma$-tocopherol was found to be lower than those reported in apricot $(93.5 \%)$, plum $(85.5 \%)$ and peach $(97.7 \%)$ kernel oils from Egypt (Hassanein, 1999), but higher than those reported for groundnut (99-389 mg/kg), palm (6-36 mg/kg), sunflower (ND-34 mg/kg), palm kernel (ND-257 $\mathrm{mg} / \mathrm{kg}$ ) oils (Rossell, 1991) and citrus seed oil (27.7-84.1 $\mathrm{mg} / \mathrm{kg}$ ) from Pakistan (Anwar et al., 2008).

The contents of $\alpha$-tocopherol and $\delta$-tocopherol ranged from 14.8-40.4 and 28.5-60.2 mg/kg respectively. The highest concentration of $\alpha$-tocopherol was exhibited for the apricot kernel oil of the var. Charmagzi $(40.4 \mathrm{mg} / \mathrm{kg})$ while the lowest was found for the var. Halmas $(14.8 \mathrm{mg} / \mathrm{kg})$. The contents of $\delta$-tocopherol were found to be higher $(60.2 \mathrm{mg} / \mathrm{kg})$ in the var. Nari, whereas the lowest $(28.5 \mathrm{mg} / \mathrm{kg}$ ) was found for the var. Halmas, among others. The contents of $\alpha$ - and $\delta$-tocopherols determined in the present investigation were found to be lower than those reported in Prunus armeniaca (5.0 and 1.5\%) and Prunus persica (traces and 2.3\%) kernel oils from Egypt (Hassanein, 1999).

The contents of $\alpha-, \gamma-$, and $\delta$-tocopherols were lower than those reported in raspberry $(71,272$ and $17 \mathrm{mg} / 100 \mathrm{~g})$, black raspberry $(50.2,105.0$, and $15.5 \mathrm{mg} / 100 \mathrm{~g})$, red raspberry $(28,31.8$ and $12.6 \mathrm{mg} / 100 \mathrm{~g})$, Korean raspberry $(41.3,111$ and $9.0 \mathrm{mg} / 100 \mathrm{~g})$, boysenberry $(13.2,137.0$ and ND $\mathrm{mg} / 100 \mathrm{~g})$ and thornless berry $(7.6,142$ and $10.9 \mathrm{mg} / 100 \mathrm{~g}$ ) seed oils (Oomah et al., 2000; Adhikari et al., 2008). The levels of tocopherols reported here are in close agreement to those of $\alpha$-tocopherol (14.89-26.87 mg/kg), $\gamma$-tocopherol (346.53-563.40 mg/kg) and $\delta$-tocopherol (8.56$18.94 \mathrm{mg} / \mathrm{kg}$ ) reported for different varieties of apricot kernel oils from Turkey (Turan et al., 2007).

The present analysis revealed that apricot seed oils are a good source of $\alpha-, \gamma$-, and $\delta$-tocopherols. Alpha-tocopherol is the most abundant form in nature having greater vitamin $E$ potency. Vitamin $E$ active compounds act as a source of natural antioxidants against oxidative deterioration of the oil, but also as a vitamin $E$ in human nutrition (Timmermann, 1990; Sies and Murphy, 1991). In nature, four different derivatives of tocopherols $(\alpha$, $\beta, \gamma$, and $\delta$ ) are found. Their antioxidant activity increases in order of $\alpha$ to $\delta$, whereas their biological activity is the opposite of antioxidant activity. Recent research has shown that $\gamma$-tocopherol is a better negative risk factor for certain types of cancer and myocardial infections than $\alpha$-tocopherol (Hensley et al., 2004; Matthaus and Ozcan, 2009).

Table 5 shows the fatty acid (FA) composition of different varieties of apricot kernel oils. Significant differences $(p<0.05)$ in the concentrations of fatty acids among the apricot kernel oils of different varieties were established. The tested apricot kernel oils mainly contained oleic (C18:1) and linoleic (C18:2) acids, which accounted for 62.34$80.97 \%$ and $13.33-30.33 \%$ of the total fatty acids, respectively.

The highest (80.97\%) and lowest (62.34\%) concentrations of oleic acid were found in the apricot kernel oil from the cvs. Charmagzi and Halmas, respectively. Whereas, the highest $(30.33 \%)$ and the lowest (13.13\%) contents of linoleic (C18:2) were shown for the cvs. Halmas and Charmagzi, respectively. When compared to other conventional and non-conventional seed oils including rapeseed (54\%), palm (43\%), soybean $(25 \%)$, almond kernel $(60.93 \%)$, berry seed (12.4$22.9 \%)$ and red raspberry (10.14-14.50), the presently analyzed apricot kernel oil contained higher proportions of oleic acid (C18:1) (Harwood and Yaqoob, 2002; Parry et al., 2005; Celik and Erciali, 2009). However, the present level of oleic acid was in good agreement with those reported for different Prunus species (43.9-78.5\%) from Turkey (Matthaus and Ozcan, 2009) and almond kernel oil (66.7-69.7\%) (Moayedi et al., 2010).

Interestingly, the amounts of oleic and linoleic acids presented in this study are generally comparable to those reported earlier (66.53-75.83\% and $17.17-26.14 \%$ ) for different apricot kernel oils (Turan et al., 2007) from Turkey. However, the amounts of both of these fatty acids were found to be higher than those reported in watermelon (18.07\% and 59.64\%), apple (26.47\% and $43.03 \%)$ and pear seed $(20.28 \%$ and $56.80 \%$ ) oils (Yukui et al., 2009). The contents of oleic acid (53.06- 
Table 5

Fatty acids composition $(\mathrm{g} / \mathbf{1 0 0 g})$ of seed oils of different varieties of apricot (Prunus armeniaca L.)

\begin{tabular}{lcccc}
\hline \multirow{2}{*}{ Fatty Acid } & \multicolumn{4}{c}{ Variety } \\
\cline { 2 - 5 } & Nari & Halmas & Travet & Charmagzi \\
\hline C16:0 & $3.35 \pm 0.07^{\mathrm{bc}}$ & $4.08 \pm 0.09^{\mathrm{b}}$ & $5.93 \pm 0.13^{\mathrm{a}}$ & $3.66 \pm 0.09^{\mathrm{b}}$ \\
$\mathrm{C} 16: 1$ & $0.71 \pm 0.01^{\mathrm{a}}$ & $0.67 \pm 0.01^{\mathrm{a}}$ & $0.42 \pm 0.09^{\mathrm{b}}$ & $0.32 \pm 0.01^{\mathrm{c}}$ \\
$\mathrm{C} 18: 0$ & $1.10 \pm 0.03^{\mathrm{c}}$ & $1.29 \pm 0.02^{\mathrm{b}}$ & $1.31 \pm 0.03^{\mathrm{b}}$ & $1.68 \pm 0.03^{\mathrm{a}}$ \\
$\mathrm{C} 18: 1$ & $70.34 \pm 1.11^{\mathrm{b}}$ & $62.34 \pm 1.34^{\mathrm{bc}}$ & $67.19 \pm 1.40^{\mathrm{b}}$ & $80.97 \pm 1.40^{\mathrm{a}}$ \\
C18:2 & $22.48 \pm 0.49^{\mathrm{ab}}$ & $30.33 \pm 0.71^{\mathrm{a}}$ & $24.41 \pm 0.51^{\mathrm{a}}$ & $13.33 \pm 0.41^{\mathrm{c}}$ \\
C18:3 & $1.03 \pm 0.04^{\mathrm{a}}$ & $0.73 \pm 0.02^{\mathrm{ab}}$ & $0.91 \pm 0.03^{\mathrm{a}}$ & - \\
TSFA & 4.45 & 5.37 & 7.24 & 5.34 \\
TUFA & 94.56 & 94.07 & 92.93 & 94.62 \\
TEFA & 23.51 & 31.06 & 25.32 & 13.33 \\
\hline
\end{tabular}

Values are means \pm SD of triplicate determinations. TSFA:total saturated fatty acids, TUFA: total unsaturated fatty acids, TEFA: total essential fatty acids. Different letters in superscript within the same row indicate significant differences among the varieties tested.

$70.90 \%)$ and linoleic acid (21.43-35.67\%) as determined in the present investigation was also comparable to those reported in different varieties of apricot kernel oil by Ozcan et al., (2010) from Turkey.

High oleic-linoleic oils are of much interest because of their superior stability and nutritional importance. Linoleic acid is recognized as one of the most important polyunsaturated fatty acids in human food because of its preventive effects for distinct heart vascular diseases (Nicolosi et al., 2004, Manzoor et al., 2007). It is widely accepted that dietary fat rich in unsaturated fatty acids prevents cardiovascular, inflammatory, atherosclerosis, autoimmune disorders, and diabetes (Ramadan et al., 2006).

The concentrations of oleic and linoleic acids in apricot seed oils, when compared with some other fruit seed oils, were lower than those reported earlier in different cultivars of Saskatoon berries (26.3-38.1\% and $47.3-60.1 \%)$, strawberry $(8.0 \%$ and $40.3 \%)$, cloudberry $(14.2 \%$ and $41.1 \%)$, cranberry $(18.7 \%$ and $38.8 \%)$, red elder berry $(14.6 \%$ and $46.1 \%)$, black bear berry $(17.5 \%$ and $40.7 \%$ ), red raspberry (11.99\% and $54.52 \%)$, black current $(10.3 \%$ and $48.2 \%)$, red current $(13.5 \%$ and $38.5)$ and mountain current (18.6\% and $36.1 \%)$ seed oils (Johansson et al., 1997).

The amount of saturated fatty acids i.e., palmitic acid (C16:0) and stearic acid (C18:0) in the tested oils ranged from $3.35-5.93 \%$ and $1.10-1.68 \%$, respectively. The contents of palmitic acid and stearic acid closely resembled those of some other fruit seed oils such as Korean raspberry (5.4\% and $2.6 \%)$, strawberry $(4.32 \%$ and $1.68 \%)$, chokecherry (3.20\% and $1.57 \%)$, and red raspberry (1.3-5.96\% and $0.7-3.09 \%$ ) seed oils (Johansson et al., 1997). The present contents of oleic, linoleic and palmitic acids were within the range (43.9-78.5\%, 9.7-37.0\% and $4.9-7.3 \%$, respectively) as reported for some Prunus cultivars from Turkey (Matthaus and Ozcan, 2009).
The results of the fatty acids of the kernel oil of different varieties of Pakistani apricot as determined in the present analysis were quite comparable with those reported earlier for Egyptian apricot kernel oil (Turan et al., 2007). The fatty acid composition of seed oils varies widely among different plant species and often the occurrence of unusual fatty acids can be used for the differentiation of particular plant families (Ozcan et al., 2011). Nevertheless, the fatty acid composition of kernel oils gives good information about the further use of the kernels or the oil. So, the evaluation of fatty acid composition is decisive for the nutritional or technical application of the oil.

\section{CONCLUSION}

Overall, the results of our present investigation revealed that the kernel of apricot locally grown in Pakistan contained appreciable amounts of oil, which is a rich source of oleic acid and $\gamma$ - tocopherols. Hence, this study may be an important contribution to the exploration of apricot kernel as a new source of oil for potential nutraceutical, functional and oleochemical uses. As apricot seed is mostly discarded as a fruit processing waste, its potential utilization for the production of valuable oils seems plausible.

\section{REFERENCE}

Abdel-Rahman MK. 2011. Can apricot kernels fatty acids delay the atrophied hepatocytes from progression to fibrosis in dimethylnitrosamine (DMN)-induced liver injury in rats. Lipids Health Dis. 10, 114.

Adawy El and Taha KM. 2001. Characterization and composition of different seed oils and flours. Food Chem. 74, 47-54. 
Adhikari P. Hwang KT, Shin MK, Lee BK, Kim SK, Kim SY, Lee KT, Kim SZ. 2008. Tocol in caneberry seed oils. Food Chem. 111, 687-690.

American Oil Chemist's Society (AOCS). 1997. Official Methods and Recommended Practices of American Oil Chemists Society, (5th Ed.) AOCS Press, Champaign, IL.

Anwar F, Naseer R, Bhanger MI, Ashraf M, Talpur FN, Aladedunye FA. 2008. Physico-chemical characteristics of citrus seeds and seed oils from Pakistan. J. Am. Oil Chem. Soc. 85, 321-330.

Asma BM, Kan T, Birhanli O. 2007.Characterization of promising apricot (Prunus armeniaca L.) genetic resources in Malatya, Turkey.Genet. Resour. Crop Evol. 54, 205-212.

Association of Official Analytical Chemists (AOAC) (1990) Official Methods of Analysis of the Association of Official Analytical Chemists, 15th edition, AOAC Inc., Virginia, Method 976.05

Baydar NG. 2001. Oil contents and oil quality properties of some grape seeds. Turk. J. Agric. For. 25, 163-168.

Celik F, Ercisli S. 2009.Lipid and fatty acid composition of wild and cultivated red raspberry fruits (RubusidaeusL.). J. Med. Plants Res. 3, 583-585.

Cerchiara T, Chidichimo G, Ragusa MI, Belsito EL, Liguori A, Arioli A. 2010. Characterization and utilization of Spanish Broom (Spartium junceum L.) seed oil. Ind Crop Prod. 31, 423-426.

Demir AD, Cronin K. 2005. Modeling the kinetics of textural changes in hazelnut during roasting. Simulat Model Pract. Theor. 13, 97-107.

Durmaz G, Alpaslan M. 2007. Antioxidant properties of roasted apricot (Prunus armeniaca L.) kernel. Food Chem. 100, 1177-1181.

Erdogen-Orhan I, Kartal M. 2011. Insight in to research on phytochemistry and biological activities of Prunus armeniaca L. (apricot). Food Res. Int. 44, 1238-1243.

Faqir MA, Saeed A, Maqam D. 2004. Storage effect on physiochemical and sensory characteristics of dried apricot jam. Pak. J. Food Sci. 14, 43-47.

Fazlin ASM, Ahmed Z, Lim HH. 2002. Compedium of medicinal plants used in Malaysia. Herbal Medicine Research Centre (HMRC), Institute for Medical Research (IMR). 2, pp 260.

Femenia A, Chen YC, Mulet A, Canellas J. 1995. Chemical composition of bitter and sweet Apricot kernels. J. Agric. Food Chem. 43, 356-361.

Gezer I, Haciseferogullari H, Ozcan MM, Arslan D, Asma BM, Unver A. 2011. Physico-chemical properties of apricot kernel. South Western J. Hortic. Bio. Environ. 2, 1-13.

Harwood JL, Yaqoob P. 2002. Nutritional and health aspects of olive oil. Eur. J. Lipid Sci. Technol. 104, 685-697.

Hassanein MM. 1999. Studies on non tradition oils: I detailed studies on different lipid profiles of some Rosaceae kernel oil. Grasas Aceites. 50, 379-384.

Hensley K, Benaksas EJ, Boli R, Comp, P, Grammas P, Hamdheydari L, Mou S, Pye QN, Stoddard MF, Wallis G, Williamson KS, West M, Wechter WJ, Floyd RA. 2004. New perspectives on vitamin $E$ : gamma tocopherol and carboxyethyl hydroxyl chroman metabolites in biology and medicine. Free Radic. Biol. Med. 36, 1-15.

Hussain I, Gulzar S, Shakir I. 2011. Physico-chemical properties of bitter and sweet apricot kernel flour and oil from North of Pakistan. Internet J. Food Safety. 13, 11-15.
Hussain A, Yasmin A, Ali J. 2010. Comparative study of chemical composition of some dried apricot varieties grown in northern areas of Pakistan. Pak. J. Bot. 42, 2497-2502.

International Organization for Standardization (ISO). 1981. Animal feeding stuffs- determination of nitrogen and calculation of crude protein content. Standard No. 5983, ISO, Geneva, Switzerland. International Organization for Standardization (ISO). 1977. Oilseed Residue Determination of Total Ash, Standard No.749, ISO, Geneva, Switzerland.

International Union of Pure and Applied Chemistry (IUPAC). 1987. Standard Methods for the Analysis of Oils, Fats and Derivatives, 7th Rev. Edition, (Eds.): C. Paquot and A. Hautfenne. Blackwell Scientific, London.

Johansson A, Laakso PI, Kallio H. 1997. Characterization of seed oils of wild, edible Finnish berries. Z. Lebensm. Unters Forsch A. 204, 300-307.

Kalyoncu IH, Ersoy N, Yilmaz M. 2009. Some physicchemical properties and mineral contents of sweet cherry (Prunusavium L.) type grown in Konya. Afr. J. Biotech. 8, 2744-2749.

Lee S, Wen J. 2001. A phylogenetic analysis of Prunusand the Amygdaloideae (Rosaceae) using ITS sequences of nuclear ribosomal DNA. Am. J. Bot. 88, 150-160.

Liangli Y, Parry JW, Zhou K. 2005. Oils from herbs, spices, and fruit seeds. In Bailey's Industrial Oil and Fat Product (F. Shahidi and A.E. Bailey, eds.) Vol. 3, chapter 9, pp. 233-258. John Wiley \& Sons, Inc, Hoboken, NJ.

Mabaleha, M.B., Y.C. Mitel, S.O. Yeboah. 2006. A comparative study of the properties of selected melon seed oils as potential candidates for development into commercial edible vegetable oils. J. Am. Oil Chem. Soc. 84, 31-36.

Manzoor M, Anwar F, Iqbal T, Bhanger MI. 2007. Physicochemical characterization of Moringa concanensis seed and seed oil. J. Am. Oil Chem. Soc. 84, 413-419.

Matthaus B, Ozcan MM. 2009. Fatty acids and tocopherol contents of some Prunus spp. Kernel oil. J. Food Lipids. 16, 187-199.

Moayedi K, Rezaei K, Moini S, Keshavarz B. 2010. Chemical Compositions of Oils from Several Wild Almond Species. J. Am. Oil Chemist Soc. DOI10.1007/ s11746-010-1701.

Moodley R, Kindness A, Jonnalagadda SB. 2007. Elemental composition and chemical characteristics of five edible nuts (almond, Brazil, pecan, macadamia and walnut) consumed in Southern Africa. J. Environ. Sci. Health B. 42, 585-591.

Naderiboldaji M, Khadivi KA, Tabatabaeefar A, Ghasemi VM and Zamani Z. 2008. Some physical properties of sweet cherry (Prunus avium L.) fruit. AmericanEruasian J. Agric. Environ. Sci. 3, 513-520.

Nehdi I, Omri S, Khalil MI, Resayes, SI. 2010. Characteristics and chemical composition of Date Palm (Phoenix canariensis) seeds and seed oil. Ind. Crop Prod. 32, 30-365.

Nehdi IA. 2011. Characteristics and composition of Washingtoniafilifera (Linden ex André) $\mathrm{H}$. Wendl. seed and seed oil. Food Chem. 126, 197-202.

Nicolosi RJ, Woolfrey B, Wilson TA, Scollin P. Handelman G, Fisher R. 2004. Decreased aortic early atherosclerosis and associated risk factors in hypercholesterolemic hamsters fed a high- or midoleic acid oil compared to a high-linoleic acid oil. J. Nut. Biochem. 15, 540-547. 
Ozcan M. 2000. Composition of some apricot (Prunus armeniaca L.) kernels grown in Turkey. Acta Aliment. 29, 289-293.

Ozcan MM, Ozalp C, Unver A, Arslan D, Dursun N. 2010. Properties of apricot kernel and oils as fruit juice processing waste. Food Nutr. Sci. 1, 31-37.

Ozcan MM, Unvera A, Erkanb E, Arslana D. 2011. Characterization of some almond kernel and oils. Food Chem. 127, 330-333.

Oderinde RA, Ajayi IA, Adewuyi A. 2009. Evaluation of the mineral nutrients, characterization and some possible uses of Blighia Unijugata Bak seed oil. EJEAF Che. 8 (2), 120-129.

Oomah BD, Ladetn S, Godfrey DV, Liang J, Girard B. 2000. Characterization of raspberry (Rubus idaeus L.) seed oil. Food Chem. 69, 187-193.

Panda H. 2004. Herbal food and its medicinal value. National Institute of Industrial Research. Kamal Nager, Dehli 110007, India. 182.

Pardo JE, Fernández E, Rubio M, Alvarruiz A. 2009. Characterization of grape seed oil from different grape varieties (Vitis vinifera). Eur. J. Lipid Sci. Technol. 111,188-193.

Parry J, Su L, Luther M, Zhou K, Yurawecz MP, Whittaker P, Yu L. 2005. Fatty Acid Composition and Antioxidant Properties of Cold-Pressed Marionberry, Boysenberry, Red Raspberry, and Blueberry Seed Oils. J. Agric. Food Chem. 53, 566-573.

Radicevic S, Cerovic R, Mitrovic O, Glisic I. 2008. Pomological characteristics and biochemical fruit composition of some Canadian sweet cherry cultivars. Acta Hortic. 795, 283-286.

Ramadan MF, Sharanabasappa G, Parmjyothi S, Seshagiri M, Moersel J-T. 2006. Profile and levels of fatty acids and bioactive constituents in mahua butter from fruit-seeds of buttercup tree [Madhucalongifolia (Koenig)]. Eur Food Res. Technol. 222, 710-718.

Rossell, JB.1991. Vegetable oil and fats. In Analysis of Oilseeds, Fats and Fatty Foods; Rossell, J. B., and Pritchard, J. L. R. Eds; Elsevier Applied Science: New York., pp 261-328.

Sies H, Murphy ME. 1991. Role of tocopherols in the protection of biological systems against oxidative damage. J. Photochem. Photobiol. B: Biol. 8, 211-224.

Timmermann F. 1990. Tocopherole - Antioxidativewirkungbeifetten und ölen. Fat Sci. Technol. 92, 201-206.

Topuz A, Topakci M, Canakci M, Akinci I, Ozdemir F. 2004. Physical and nutritional properties of four orange varieties. J. Food Eng. 66, 519-523.

Turan S, Topcu A, Karabulut I, Vural H, Hayaloglu AA. 2007. Fatty acid, triacylglycerol, phytosterol, and tocopherol variation in kernel oil of Malatya apricots from Turkey. J. Agric. Food Chem. 55, 1078710794.

Wen J, Berggren ST, Lee C-H, Ickert-Bond S, Yi T-S, Yoo K-O, Xie L, Shaw J, Potter D. 2008. Phylogenetic inferences in Prunus (Rosaceae) using chloroplast $n d h \mathrm{~F}$ and nuclear ribosomal ITS sequences. J. Syst. Evol. 46, 322-332.

Wrolstad RE. 2003. Analysis of tocopherols and tocotrienols. In: Current Protocols in Food Analytical Chemistry; (Ed.) R.E. Wrolstad. John Wiley \& Sons, U.K.

Yukui R, Wenya W, Rashid F, Qing L. 2009. Fatty acid composition of apple and pear seed oils. Int. J. Food Prop. 12, 774-779.

Recibido: 9/9/11 Aceptado: 12/12/11 